\title{
Effect of Modern Agricultural Practices on Biological Properties of Rhizospheric and non Rhizospheric Soils of Chaka Block of Allahabad District, U.P. India
}

\author{
Rohit Singh $^{1 *}$, Ram Bharose ${ }^{1}$ and Vijay Kant Singh ${ }^{2}$ \\ ${ }^{1}$ Department of Environmental Science, School of Forestry \& Environmental Science, \\ SHUATS, Allahabad-211007, U.P. India \\ ${ }^{2}$ Department of Soil Science, College of Agriculture, G B Pant University of Agriculture \& \\ Technology, Pantnagar-263145, Uttarakhand, India \\ *Corresponding author
}

\section{Keywords}

Modern agriculture, Microbial diversity, Survival efficiency, Phosphorus solubilizing

Article Info

Accepted:

12 November 2018 Available Online:

10 December 2018

\section{A B S T R A C T}

Soil is the habitat of one of the most complex of natural biological coin munities in which all the phenomena associated with the struggle for survival occur. This competition is greatly intensifies in the root zone of plants, the rhizosphere, owing to the greater density of its micro population. The Experiment was carried out in the in laboratory of Department of Environmental Science, SHUATS, Allahabad to study the effect of Modern agricultural practices on soil microbial properties of Chaka block of Allahabad district" U.P., INDIA in 2016. The soil samples were collected during January to April 2016 rabi season from 12 sites of farmer's field and analyzed for total bacteria, phosphorus solubilization, survival of Bacillus spp. in lead $(\mathrm{Pb})$ contaminated soil. In microbiological analysis for diversity in species of Rhizospheric soil samples were found Bacillus spp. and non-rhizospheric soil samples were found Coccus spp. of bacteria. In few samples of Rhizospheric and Nonrhizospheric soil of different villages of Chaka block were found PSB. The bacterial count range from $98 \times 10^{5}-18 \times 10^{6} \mathrm{CFU} \mathrm{g}^{-1}$ soil in rhizospheric soil and from $87 \times 10^{5}-18 \times 10^{6}$ $\mathrm{CFU} \mathrm{g}^{-1}$ soil in non-rhizospheric soil. In rhizospheric soil gram positive bacteria were found in maximum villages, whereas in non- rhizospheric soil all villages were found gram negative bacteria, except some villages. The range of zone of phosphate-solubilizing bacteria was $3.5-3.7 \mathrm{~cm}$ in rhizospheric soil and $1.5-2.8 \mathrm{~cm}$ in non rhizospheric soil. Diversity in species of Rhizospheric soil was found Bacillus spp and Non-rhizospheric soil was found Coccus spp of bacteria. The range of survival efficiency of Bacillus spp. was 83.47-97.76 found at lead concentration $250 \mathrm{mg} \mathrm{L}^{-1}$ in rhizospheric soil. The survival efficiency of Bacillus spp was also found in decreasing order with increase in concentration of lead in Rhizospheric soil sample.

\section{Introduction}

The indiscriminate use of pesticides disturbs the soil environment by affecting flora and fauna including micro-flora of soil. The important micro-flora, beneficial for the growth of plants includes nitrogen fixing bacteria and phosphate solubilizing bacteria, 
present in the rhizosphere of the plant. The excess application of these pesticides may adversely affect the function of these rhizospheric microorganisms. Since the fertility of the soil depends on the number and type of microorganisms present in the soil Sarnaik et al., (2006).

The rhizosphere is surrounding the plant root surface and being affected by plant root activities. Plant roots secrete mucigel (Jenny and Grossen-bacher, 1963) to supply carbohydrate sources to soil micro-organisms (Jimenez et al., 2003). The rhizospheric region is the root influence by enhanced microbial activity. Rhizosphere region provides better sites for the survival and isolation of beneficial microorganisms than the bulk soil. The physico-chemical properties of the region create different growing condition for microorganisms in comparison to root free soil (Bibhuti et al., 2011). The diversity and functions of microbes in the rhizosphere, a narrow region around the root, are related to the root exudates (proteins and sugars), biogeochemical reactions and respiration (Narula et al., 2009). A plant is a partner in the biocenotic system and all the physiological changes it undergoes during vegetation are reflected in the feature of coexisting microorganisms.

Soil bacteria and fungi play pivotal roles in various biogeochemical cycles (BGC) (Wall and Virginia, 1999) and are responsible for the cycling of organic compounds. Soil microorganisms also influence above-ground ecosystems by contributing to plant nutrition (George et al., 1995, Timonen et al., 1996), plant health (Smith and Goodman, 1999), soil structure (Dodd et al., 2000) and soil fertility (O’Donnell et al., 2001). Forestland soil microorganisms, involved in soil energy cycling processes, play an important role in producing available nutrients for the crop.
A feed probiotics is defined as "a living microbial supplements that positively affects hosts by modifying the host-associated microbial community, improves food degradation by enhancing its nutritional value, and improves the quality of the environmental parameters" (Verschuere et al., 2000).

Use of wastewater to irrigate agricultural lands is one of common practice in suburban and industrial areas in many parts of the world (Sharma et al., 2007 Gupta et al., 2008). Waste water irrigation leads to accumulation of heavy metals in the soil (Singh et al., 2004.)

Rhizosphere processes are important for plant growth as they improve root growth, enhance nutrient acquisition and protect crop against pests and pathogens (Romheld and Neumann, 2006).

Best management practices for soil rhizosphere system should be based on the knowledge of rhizosphere processes to achieve desired improvements in plant growth and health with less agrochemical inputs. The farmers are applying both inorganic and organic fertilizers in an increasing rate to produce more and more crops. Microbes which solubilize the bound phosphate and rock phosphate into simple are called phosphate solubilizer. They secret organic acids such as formic acid, lactic acid, succinic acid, propionic acid and hydroxyl acid to solubilize the bound phosphate in the soil. Till now, the information on the phosphate solubilizing actinomycetes is scanty. Therefore the present investigation was designed to study the phosphate solubilizing actinomycetes (Balakrishna et al., 2012).

Therefore, monitoring of soil biological parameters is must to know the present situation of soil. Keeping in view the facts, the present study was undertaken to evaluate the effect of modern agricultural practices on 
biological properties of rhizospheric and non rhizospheric soils of chaka block of Allahabad district, U.P.

\section{Materials and Methods}

\section{Study site and sampling sites}

Block Chaka is situated on the right bank adjacent to Yamuna river in south of Allahabad city, which is located at $25.80{ }^{0} \mathrm{~N}$ Latitude and $81.50^{\circ} \mathrm{E}$ Longitude and 98 meter above the sea level. It comes under subtropical and semi-arid climate (Fig. 1). Rhizosphere and non rhizosphere samples were collected from agricultural filed of farmers of Chaka block, Allahabad, India. The samples were collected randomly and carefully from the farmer's field. Location of sampling sites was given in table 1. The soil samples were brought to the laboratory and the rhizosphere soils adhering to the plant roots were collected very carefully by tapping the roots. A known amount of rhizosphere soil sample were taken immediately from each field and processed for serial dilution study of the microorganisms.

\section{Sterilization of glassware and media used}

The glass wares like test tubes, screw cap test tubes, petridishes and pipettes used in microbial study was cleaned, washed with distilled water and then sterilized into autoclave at $121^{\circ} \mathrm{C}$ under pressure of 15 Psi for about 20 minutes. The nutrient agar media was used for the isolation and maintenance of bacteria isolates during the microbial count or $\mathrm{CFU} / \mathrm{ml}$ bacteria isolates from rhizospheric and non-rhizospheric soil samples. Composition of nutrient agar media is given in table 2.

\section{Isolation and total bacterial count}

This was achieved by serial dilution method. Six test tubes containing $9 \mathrm{ml}$ of sterile distilled water was taken. One test tube containing $10 \mathrm{ml}$ of sterile distilled water was taken. $1 \mathrm{~g}$ of soil was added to the test tube with $10 \mathrm{ml}$ of sterile distilled water. Mixing was done properly. Then $1 \mathrm{ml}$ of microbial suspension was added to another test tube containing $9 \mathrm{ml}$ of sterile distilled water. Again mixing was performed properly $1 \mathrm{ml}$ of microbial suspension was added to another test tube containing $9 \mathrm{ml}$ sterile distilled water. This step was repeated serially for other test tubes. In this way the microbial suspension get 10 fold serially diluted.100 $\mu \mathrm{l}$ of diluted suspension was poured into the surface of Nutrient agar plate and spread by "L" shaped spreader. The bacteria can thus be isolated and counted by C.F.U i.e. Colony Forming Unit.

C.F.U=No: of colonies/inoculum size (g) $\mathrm{X}$ Dilution Factor

\section{Culture medium and Heavy metal exposure}

Bacillus spp. bacterial cell was grown in broth nutrient agar media (10g peptone, $5 \mathrm{~g}$ beef extract, 5g Nacl per $1000 \mathrm{ml}, \mathrm{pH}$ 7.0) than diluted the different concentrations $(50 \mathrm{mg}$ $\mathrm{ml}^{-1}, 100 \mathrm{mg} \mathrm{ml}^{-1}, 150 \mathrm{mg} \mathrm{ml}^{-1}, 200 \mathrm{mg} \mathrm{ml}^{-1}$, $250 \mathrm{mg} \mathrm{ml}^{-1}$ ) of lead acetate. Mixed in 1:100 proportions of $\mathrm{Pb}$ and nutrient agar media, then sterilized in the autoclave $121^{\circ} \mathrm{C}$ for 30 minutes.

Thereafter $1 \mathrm{ml}$ aliquot of Bacillus ssp. suspension (24 hr old) was inoculated in 250 $\mathrm{ml}$ Erlenmeyer flask with $50 \mathrm{mg} \mathrm{ml}^{-1}, 100 \mathrm{mg}$ $\mathrm{ml}^{-1}, 150 \mathrm{mg} \mathrm{ml}^{-1}, 200 \mathrm{mg} \mathrm{ml}^{-1}, 250 \mathrm{mg} \mathrm{ml}^{-1}$ ) of lead supplemented medium [Lead acetate trihydrate $\left.\left(\mathrm{CH}_{3} \mathrm{COO}\right)_{2} \mathrm{~Pb} .3 \mathrm{H}_{2} \mathrm{O}\right]$.

The optical density of suspension was measured before incubation and after incubation at $660 \mathrm{~nm}$ and after incubation in incubator at $37^{\circ} \mathrm{C}$ temperature and $48 \mathrm{hrs}$ (ElSayed et al., 2008). 
Screening of phosphorus and potassium solubilizing bacteria

Primary phosphorus solubilizing activity of Bacillus spp. Isolation was carried out by allowing the bacteria and fungi to grow in selective media i.e. Pakovaskaya's agar for media for bacteria $24-48 \mathrm{hr}$ at $37^{\circ} \mathrm{C}$. The composition of Pikauskaya's media is given in table 3. The appearance of a transparent halo zone around the fungi and bacteria colony indicate the phosphorus solubilizing activity of the bacteria record the colony and zone diameter at 24-48 hour (Pikovskaya, 1948).

\section{Results and Discussion}

\section{Total bacterial count (C.F.U.)}

The results revealed in figure 2 shows that the maximum total bacteria $98 \times 10^{5} \mathrm{CFU} \mathrm{g}^{-1}$ soil and $82 \times 10^{6} \mathrm{CFU} \mathrm{g}{ }^{-1}$ soil of rhizospheric soil was found at Mohabatganj Uparhar village while the minimum total bacteria $31 \times 10^{5} \mathrm{CFU}$ $\mathrm{g}^{-1}$ soil and $18 \times 10^{6} \mathrm{CFU} \mathrm{g^{-1 }}$ soil was recorded at Sarapatahiya village, which gave the significant difference in soil C.F.U values at different villages of Chaka block.

The maximum soil total bacteria $87 \times 10^{5} \mathrm{CFU}$ $\mathrm{g}^{-1}$ soil and $74 \times 10^{6} \mathrm{CFU} \mathrm{g}{ }^{-1}$ soil in non rhizospheric soil was found at Mohabatganj Uparhar village while the minimum total bacteria $19 \times 10^{5} \mathrm{CFU} \mathrm{g}{ }^{-1}$ soil and $18 \times 10^{6} \mathrm{CFU}$ $\mathrm{g}^{-1}$ soil was found Sarapatahiya which shows the significant difference between other villages of Chaka block. It may be due to due presence of OM, application of FYM, cropping paten and use of pesticides and chemical fertilizer in the soil in different sites of villages. The application of fertilizer increased the soil fertility level, the number of microorganisms and also agricultural practices particularly input of manure and cover crop has large impact on the size and activity of soil microbial population Tilak et al, 1995.
The enrichment of soil nitrogen through biological fixation of nitrogen by the host legume plant could have also affected the microbial diversity (Bardgett et al, 1999).

\section{Morphologoly and Zone of phosphate solubilizing bacteria $(\mathbf{c m})$}

Results of morphological and Zone of phosphate solubilizing bacteria $(\mathrm{cm})$ shown in Table 4 shows that the gram positive bacteria of rhizospheric (R) soil was found in Chaka, Chaka Kriparam, Bharuha, Dadari Taluka Naini, Maduka Kacchar, Dadari ta Naugawa, Mohabatganj Uparhar, Baswar, Dhanuha villages while, the gram negative bacteria was recorded at Sarapatahiya, Arail, Mahewa Patti Purb Kacchar villages. The colonies color creamy and rod shape was found. The maximum diameter of phosphate-solubilizing was found at Mohabatganj Uparhar $(3.7 \mathrm{~cm}$ ) and Dadari Ta Naugawa $(3.5 \mathrm{~cm})$ and minimum Dadari Taluka Naini $(1.5 \mathrm{~cm})$ in rhizospheric soil of different villages of Chaka block.

The non-rhizospheric (NR) soil Sarapatahiya, Mahewa Patti Purb Kacchar was found gram positive bacteria and Chaka, Chaka Kriparam, Bharuha, Dadari Taluka Naini, Arail, Maduka Kacchar, Dadari Ta Naugawa, Mohabatganj Uparhar, Baswar, Dhanuha was found gram negative bacteria in soil.

The colonies color creamy and Spherical shape was found. The maximum phosphatesolubilizing was found at Mohabatganj Uparhar $(2.8 \mathrm{~cm})$ and Dadari Ta Naugawa (2.6 $\mathrm{cm})$ and minimum Bharuha $(1.5 \mathrm{~cm})$ at different villages of Chaka block.

It may be due to the genus Bacillus spp. was more frequently isolated from soil irrigated with canal water Bahig et al., 2008 and cropping pattern in the soil in different sites of villages. 
Table.1 Sampling sites

\begin{tabular}{|l|c|c|c|c|}
\hline Sampling sites & $\begin{array}{c}\text { Site } \\
\text { notation }\end{array}$ & Distance & Latitudes & Longitudes \\
\hline Chaka & $\mathrm{S} 1$ & $0 \mathrm{~km}$ & $25.390 \mathrm{~N}$ & $81.830 \mathrm{E}$ \\
\hline Chaka Kriparam & $\mathrm{S} 2$ & $3.1 \mathrm{~km}$ & $25.360 \mathrm{~N}$ & $81.850 \mathrm{E}$ \\
\hline Bharauha & $\mathrm{S} 3$ & $4.6 \mathrm{~km}$ & $25.350 \mathrm{~N}$ & $81.870 \mathrm{E}$ \\
\hline Sarapatahiya & $\mathrm{S} 4$ & $3.8 \mathrm{~km}$ & $25.380 \mathrm{~N}$ & $81.880 \mathrm{E}$ \\
\hline Dadari Taluka Naini & $\mathrm{S} 5$ & $4.0 \mathrm{~km}$ & $25.370 \mathrm{~N}$ & $81.860 \mathrm{E}$ \\
\hline Arail & $\mathrm{S} 6$ & $3.6 \mathrm{~km}$ & $25.400 \mathrm{~N}$ & $81.890 \mathrm{E}$ \\
\hline Mahewa Patti PurbKacchar & $\mathrm{S} 7$ & $2.6 \mathrm{~km}$ & $25.410 \mathrm{~N}$ & $81.830 \mathrm{E}$ \\
\hline Madauka Kacchar & $\mathrm{S} 8$ & $6.9 \mathrm{~km}$ & $25.390 \mathrm{~N}$ & $81.820 \mathrm{E}$ \\
\hline Mohabatganj Uparhar & $\mathrm{S} 9$ & $8.0 \mathrm{~km}$ & $25.420 \mathrm{~N}$ & $81.810 \mathrm{E}$ \\
\hline Dadari Ta Naugawa & $\mathrm{S} 10$ & $5.0 \mathrm{~km}$ & $25.370 \mathrm{~N}$ & $81.830 \mathrm{E}$ \\
\hline Baswar & $\mathrm{S} 11$ & $16.0 \mathrm{~km}$ & $25.370 \mathrm{~N}$ & $81.810 \mathrm{E}$ \\
\hline Dhanuha & $\mathrm{S} 12$ & $4.0 \mathrm{~km}$ & $25.380 \mathrm{~N}$ & $81.830 \mathrm{E}$ \\
\hline
\end{tabular}

Table.2 Composition of nutrient agar media

\begin{tabular}{|c|c|}
\hline COMPOSITION & AMOUNT \\
\hline Peptone & $5.0 \mathrm{~g} \mathrm{~L}^{-1}$ \\
\hline Beef extract & $3.0 \mathrm{~g} \mathrm{~L}^{-1}$ \\
\hline Sodium chloride & $5.0 \mathrm{~g} \mathrm{~L}^{-1}$ \\
\hline pH & 7.0 \\
\hline Agar & $15-20 \mathrm{~g}$ \\
\hline Water & $1000 \mathrm{ml}$ \\
\hline
\end{tabular}

Table.3 Composition of Pikauskaya's media

\begin{tabular}{|c|c|}
\hline COMPOSITION & AMOUNT \\
\hline Glucose & $10.0 \mathrm{gL}^{-1}$ \\
\hline Calcium phosphate & $5.0 \mathrm{gL}^{-1}$ \\
\hline Yeast extract & $0.5 \mathrm{gL}^{-1}$ \\
\hline Ammonium sulfate & $0.5 \mathrm{gL}^{-1}$ \\
\hline Potassium chloride & $0.2 \mathrm{gL}^{-1}$ \\
\hline Magnesium sulfate & $0.1 \mathrm{gL}^{-1}$ \\
\hline Sodium chloride & $0.2 \mathrm{gL}^{-1}$ \\
\hline Magnous sulfate & $0.02 \mathrm{gL}^{-1}$ \\
\hline Ferrous sulfate & $0.02 \mathrm{gL}^{-1}$ \\
\hline Agar & $15 \mathrm{gL}^{-1}$ \\
\hline pH & 7.0 \\
\hline Water & $1000 \mathrm{ml}$ \\
\hline
\end{tabular}


Table.4 Variation in morphological and Zone of phosphate solubilizing bacteria $(\mathrm{cm})$ isolated from Rhizospheric and Non-rhizospheric soil of villages of Chaka block

\begin{tabular}{|c|c|c|c|c|c|c|c|c|}
\hline \multirow[t]{2}{*}{ Sites } & \multicolumn{2}{|c|}{ Gram staining } & \multicolumn{2}{|c|}{ Colony color } & \multicolumn{2}{|c|}{ Shape } & \multicolumn{2}{|c|}{$\begin{array}{l}\text { Zone of phosphate- } \\
\text { solubilizing }\end{array}$} \\
\hline & $\mathbf{R}$ & NR & $\mathbf{R}$ & NR & $\mathbf{R}$ & NR & $\mathbf{R}$ & NR \\
\hline Chaka & Gram +ve & Gram -ve & Creamy & Creamy & Rod & Spherical & $2.5 \mathrm{~cm}$ & $1.8 \mathrm{~cm}$ \\
\hline Chaka Kriparam & Gram +ve & Gram -ve & Creamy & Creamy & Rod & Spherical & & - \\
\hline Bharuha & Gram +ve & Gram -ve & Creamy & Creamy & Rod & Spherical & $2.3 \mathrm{~cm}$ & $1.5 \mathrm{~cm}$ \\
\hline Sarapatahiya & Gram +ve & Gram -ve & Creamy & Creamy & Rod & Spherical & - & - \\
\hline Dadari Taluka Naini & Gram +ve & Gram -ve & Creamy & Creamy & Rod & Spherical & $1.5 \mathrm{~cm}$ & - \\
\hline Arail & Gram -ve & Gram -ve & Creamy & Creamy & Rod & Spherical & - & - \\
\hline $\begin{array}{l}\text { Mahewa Patti } \\
\text { PurbKacchar }\end{array}$ & Gram -ve & Gram +ve & Creamy & Creamy & Rod & Spherical & $2.5 \mathrm{~cm}$ & - \\
\hline Maduka Kacchar & Gram -ve & Gram -ve & Creamy & Creamy & Rod & Spherical & $2.5 \mathrm{~cm}$ & $1.6 \mathrm{~cm}$ \\
\hline Mohabatganj Uparhar & Gram +ve & Gram -ve & Creamy & Creamy & Rod & Spherical & $3.3 \mathrm{~cm}$ & $2.8 \mathrm{~cm}$ \\
\hline Dadari Ta Naugawa & Gram +ve & Gram -ve & Creamy & Creamy & Rod & Spherical & $3.7 \mathrm{~cm}$ & $2.6 \mathrm{~cm}$ \\
\hline Baswar & Gram +ve & Gram -ve & Creamy & Creamy & Rod & Spherical & $2.9 \mathrm{~cm}$ & $1.8 \mathrm{~cm}$ \\
\hline Dhanuha & Gram +ve & Gram -ve & Creamy & Creamy & Rod & Spherical & $2.8 \mathrm{~cm}$ & $1.9 \mathrm{~cm}$ \\
\hline
\end{tabular}

Fig.1 Geographical location of sampling area
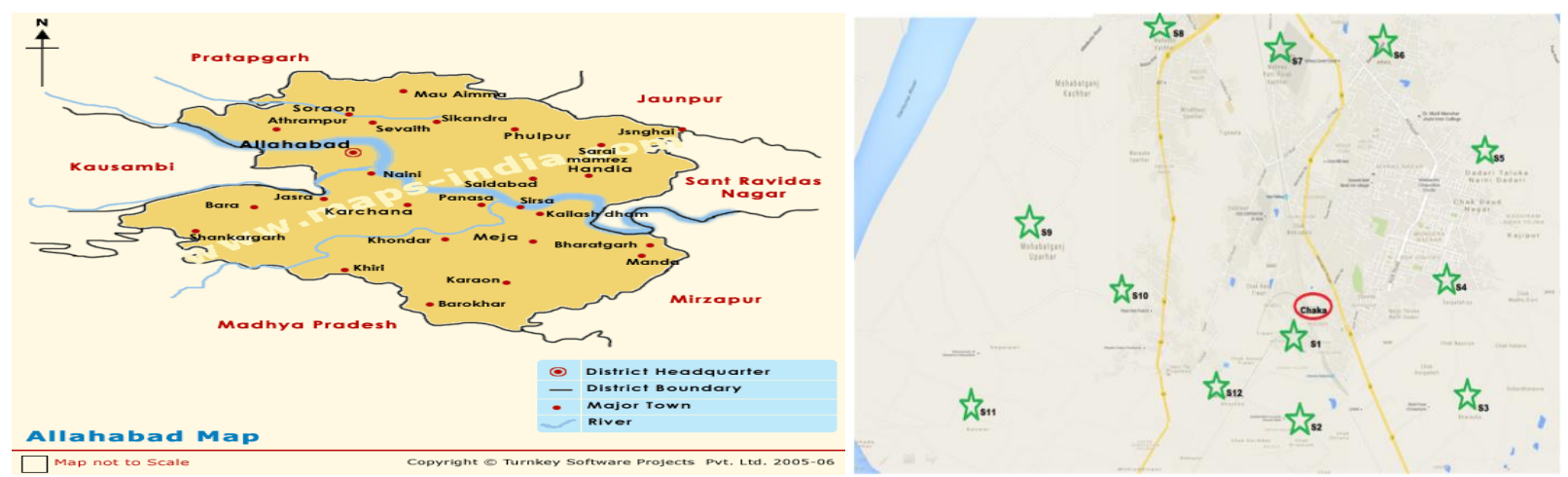

Fig.2 Variation in isolated total bacteria C.F.U. of Rhizospheric and Non-rhizospheric soil of different villages of Chaka block

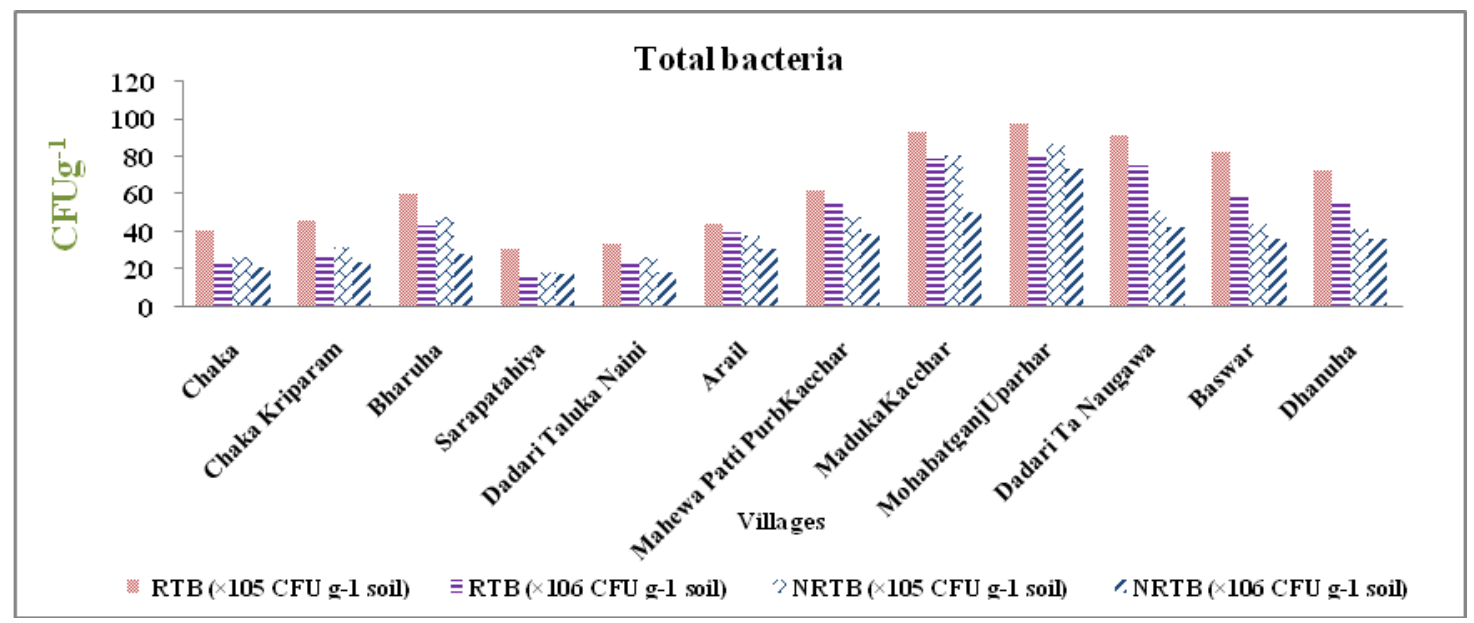


Fig.3 Variation of different lead concentration on survival efficiency of Bacillus spp. isolated from rhizospheric soil of different villages of Chaka block

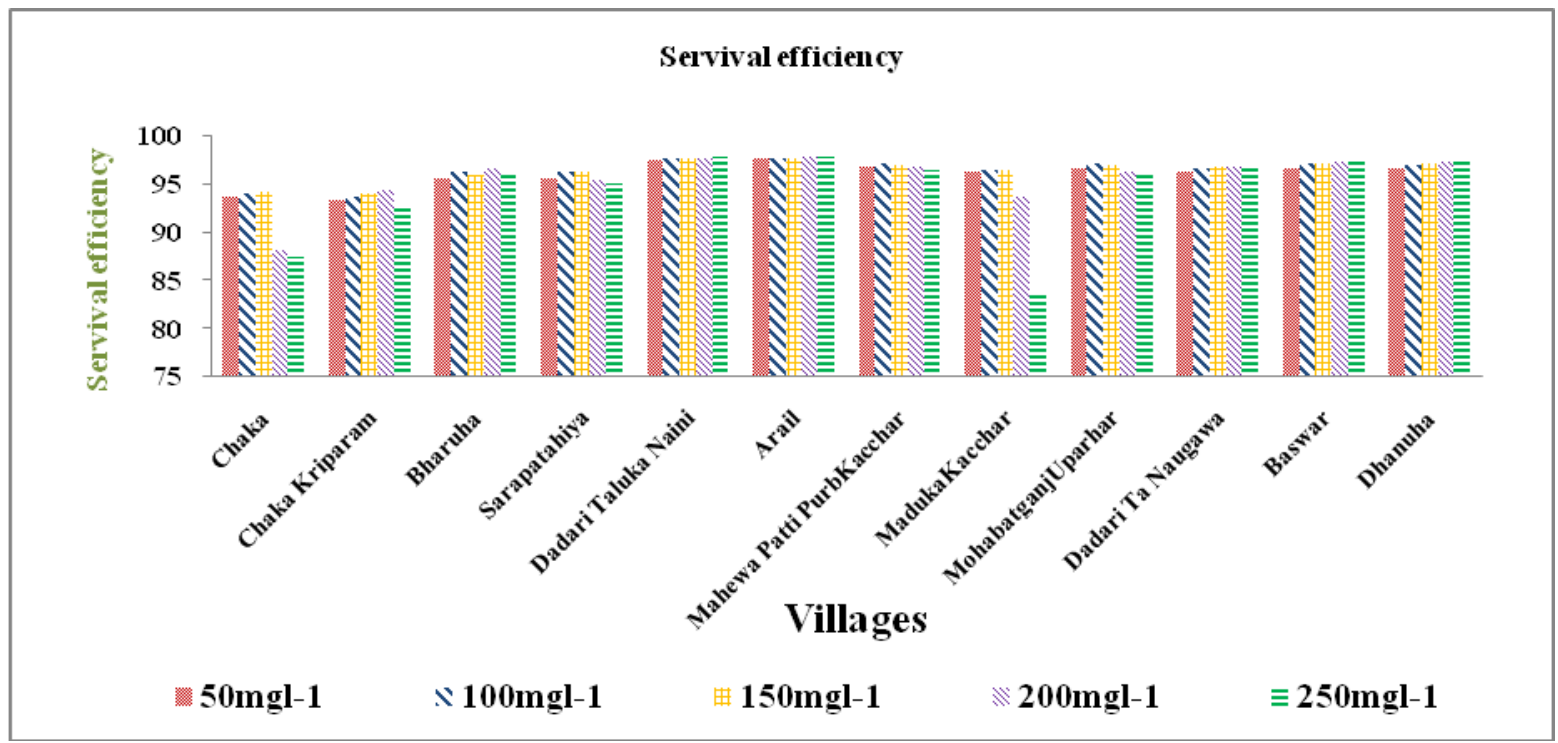

Survival efficiency of Bacillus spp. in different lead concentration

The results presented figure 3 shows that the effect of lead concentrations on survival efficiency of Bacillus spp. isolated from rhizospheric soil of different villages of Chaka block was found significant.

The maximum $(97.76 \%)$ survival efficiency of Bacillus spp. was found at lead concentration $250 \mathrm{mg} \mathrm{l}^{-1}$ in rhizosphere soil of Arail village of Chaka block. The minimum (83.47\%) survival efficiency of Bacillus spp. was found at lead concentration $250 \mathrm{mg} \mathrm{l}^{-1}$ in rhizosphere soil of Madauka Kacchar village of Chaka block. The result shows trend of survival efficiency in rhizospheric soil of Arail, Dadari Taluka Naini, Baswar and Dhanuha the survival efficiency increased as increased concentration of $\mathrm{Pb}$. The survival efficiency trend from 50 to $250 \mathrm{mg} \mathrm{l}^{-1}$ was $97.53 \%, 97.56 \%, 97.62 \%, 97.68 \%$ and $97.76 \%$. The trend for minimum survival efficiency was found 50 to $250 \mathrm{mg} \mathrm{l}^{-1}$ $96.27 \%, 97.34 \%, 96.38 \%, 93.66 \%, 83.47 \%$ in rhizospheric soil of Madauka Kacchar. The survival efficiency of Bacillus spp. in soil of Chaka, Sarapatahiya, Dadari Taluka Naini and Dadari Ta Naugawa was recorded increasing 50 to $150 \mathrm{mg} \mathrm{l}^{-1}$ and decreased 200 to $250 \mathrm{mg} \mathrm{l}^{-1}$. The survival efficiency of Bacillus spp. in soil of Mahewa Patti Purb Kacchar, Mohabatganj Uparhar was recorded increasing 50 to $100 \mathrm{mg} \mathrm{l}^{-1}$ and decreased 150 to $250 \mathrm{mg} \mathrm{l}^{-1}$. The survival efficiency of Bacillus spp. in soil of Chaka Kriparam, Bharuha was recorded increased 50 to $200 \mathrm{mg}$ $1^{-1}$ and decreased $250 \mathrm{mg} \mathrm{l}^{-1}$. The survival efficiency of Bacillus spp. in soil of Arail, Dadari Taluka Naini, Baswar and Dhanuha was recorded increased 50 to $250 \mathrm{mg} \mathrm{l}^{-1}$. It may be due to excess use of pesticide in the soil in different fields of villages. Bacillus spp. is the most abundant genus in the PGPR activity of some of these strains has been known for many years resulting in a broad knowledge of the mechanism involved. Strongly effect the environment by increasing nutrient availability of the plant. Bacillus spp. is naturally present in the immediate vicinity of plant root. Bacillus spp. is able to maintain stable contact with higher plant and promote their growth. Bacillus spp. used as bio- 
fertilizers probably have direct effect on plant growth through the synthesis of plant growth hormones (Amer and Utkhede, 2007). Phosphate solubilizing Bacillus spp. stimulates plant growth through enhanced $\mathrm{P}$ nutrient increase sing the uptake of NPK and Fe. Bacillus spp. is very consistent in improving different root parameter (root performance, root length, dry mater and content of root) in mint (Kayamk et al., 2008).

It is concluded that, in microbiological analysis for diversity in species of Rhizospheric soil was found Bacillus spp. and Non-rhizospheric soil was found Coccus spp. of bacteria. The phosphorus-solubilizing bacteria were also found in Rhizospheric and Non-rhizospheric soil of different villages of Chaka block, except few villages (Chaka Kriparam, Sarapatahiya, Arail). PSB in Nonrhizospheric soil Dadari Taluka Naini and Mahewa Patti Purb Kacchar. The survival efficiency of Bacillus spp. was also found in decreasing order with increase in concentration of lead in Rhizospheric soil sample except in Dadari Taluka Naini, Arail, Baswar and Dhanuha.

\section{References}

Amar, A.G. and Utkhede, R.S. (2007). Development of formulation of biological agent for management of root rot of lettuce and cucumber. Canadian Journal of Microbialogy, 46: 809-819.

Bahig, A.E., Aly, E.A., Khaled, A.A. and Amel, K.A. (2008). Isolation, characterization and application of bacterial population from agricultural, soil at Sohag Province, Egypt. Malaysian Journal of Microbiology, 4 (2): 42- 50.

Balakrishna, G., Shanker, A.S. and Pindi, P.K. (2012). Isolation of Phosphate Solibulizing Actinomycetes from Forest
Soils of Mahabubnagar District, IOSR, Journal of Pharmacy. 2 (2): 271-275.

Bardgett, R.D. and Shine, A. (1999). Linkages between plant litter diversity, soil microbial biomass and ecosystem function in temperate grasslands. Soil Biology \& Biochemistry. 31: 317-321.

Bibhuti, B.D. and Dkhar, M.S. (2011): Rhizosphere Microbial Populations and Physico Chemical Properties as Affected by Organic and Inorganic Farming Practices, American-Eurasian, J. Agric. \& Environ. Sci. 10 (2): 140150.

Dodd, J.C., Boddington, C.L., Rodriguez, A., Gonzalez-Chavez, C. and Mansur, I. (2000). Mycelium of arbuscular mycorrhizal fungi (AMF) from different genera form, function and detection. Plant Soil. 226: 131-151.

El-Sayed, M. S., Rehab, M. M., and Ahmed, A. S (2008). Behavioral response of resistant and sensitive Pseudomonas aeruginosa S22 isolated from Sohag Governorate, Egypt to cadmium stress. Afr. J. Biotechnol., 7(14): 2375-2385.

George, E., Marschner, H. and Jakobsen, I. (1995). Role of arbuscular mycorrhizal fungi in uptake of phosphorous and nitrogen from soil. Crit. Rev. Biotechnol., 15: 257-270.

Gupta, N., Khan, D. K. and Santra, S. C. (2008). An assessment of heavy metal contamination in vegetables grown in wastewater-irrigated areas of Titagarh, West Bengal, India. Bulletin of Environmental Contamination and Toxicology. 80: 115-118.

Jenny, H., and Grossenbacher, K. (1963). Root-soil boundary zone as seen in the electron microscope, Soil Sci. Soci. Am. J., 27: 273-277.

Jimenez, M.B., Flores, S.A., Zapata, E.V., Campos, E.P., Bouquel. Et. S. and Zenteno, E. (2003). Chemical characterization of root exudates from 
rice (Oryza sativa) and their effects on the chemo-tactic response of endophytic bacteria. Plant Soil. 249: 271-277.

Kayamk, H.C., Yarali, F., Guvence, I. and Donmiz, M. F. (2008). The effect of inoculation with plant growth rhizobateria (PGPR) on root formation of mint (Mentha piperata L.) culling. Afr. J. Biotechnol., 7(24): 4479-4483.

Narula, N., Kothe, E. and Behl, R.K. (2009). Role of root exudates in plant-microbe interactions. J Appl Bot Food Qual., 82.122-130.

O’Donnell, A. G., Seasman, M., Macrae, A., Waite, I. and Davies, J.T. (2001). Plants and fertilisers as drivers of change in microbial community structure and function in soils. Plant Soil, 232: 135145.

Pikovskaya, R.I. (1948). Mobilization of phosphorus in soil connection with the vital activity of some microbial species. Microbiologiya, 17: 362-370.

Römheld, V. and Neumann, G. (2006). The Rhizosphere: Contributions of the soilRoot Interface to Sustainable Soil Systems. In: Uphoff, N. et al., (ed.) Biological Approaches to Sustainable Soil Systems. CRC Press, Boca Raton, FL. pp: 91-107.

Sarnaik, S.S., Kanekar, P.P, Raut, V.M., Taware, S.P., Chavan, K.S. and Bhadbhade, B.J. (2006). Effect of application of different pesticides to soybean on the soil microflora. Journal of Environmental Biology, 27 (2): 423426.

Sharma, R. K., Agrawal, M. and Marshall, F. (2007). Heavy metal contamination of soil and vegetables in suburban areas of Varanasi, India. Ecotoxicology and Environmental Safety. 66: 258-266.

Singh, K. P., Mohan, D., Sinha, S. and Dalwani, R. (2004). Impact assessment of treated/untreated wastewater toxicants discharged by sewage treatment plants on health, agricultural, and environmental quality in the wastewater disposal area. Chemosphere, 55: 227-255.

Smith, K. P. and Goodman, R. M. (1999). Host variation for interactions with beneficial plant- associated microbes. Annu. Rev. Phytopathol, 37: 473-491.

Tilak, K. V. B. R., Saxena, A. K., and Sadasivam, K. V. (1995). Synergistic effects of phosphate solubilizing bacterium Pseudomonas striata and arbuscular mycorrhizae on soybean. Mycorrhizae: biofertilizers for the future. Tata Energy Research Institute, New Delhi, 224-226.

Timonen, S., Finlay, R.D., Olsson, S. and Soderstrom, B. (1996). Dynamics of phosphorous translocation in intact ectomycorrhizal systems: nondestructive monitoring using a Bscanner. FEMS Microbiol. Ecol. 19, $171-180$.

Verschuere, L., Rombaut, G. and Sorgeloos, P. (2000). Probiotic bacteria as biological agents in aquaculture. Microbiology and Molecular Biology Reviews, 64(4): 655-671.

Wall, D.H. and Virginia, R.A. (1999): Controls on soil biodiversity: insights from extreme environments. Appl. Soil Ecol.13: 137-150.

\section{How to cite this article:}

Rohit Singh, Ram Bharose and Vijay Kant Singh. 2018. Effect of Modern Agricultural Practices on Biological Properties of Rhizospheric and non Rhizospheric Soils of Chaka Block of Allahabad District, U.P. India. Int.J.Curr.Microbiol.App.Sci. 7(12): 1496-1504. doi: https://doi.org/10.20546/ijcmas.2018.712.176 